http:/www.journals.zu.edu.eg/journalDisplay.aspx?Journalld=1\&queryType=Master

\title{
CHEMICAL COMPOSITION, PROTEOLYSIS, RHEOLOGICAL AND ORGANOLEPTIC PROPERTIES OF CHEDDAR CHEESE AS AFFECTED By VARIOUS HIGH HYDROSTATIC PRESSURE TREATMENTS DURING RIPENING
}

\author{
Ali A. Abd El-Galeel ${ }^{{ }^{*}}$ and A.A. El-Zawahry ${ }^{2}$ \\ 1. Food Sci. Dept., Fac. Agric., Zagazig Univ., Egypt \\ 2. Dairy Technol. Dept., Anim. Prod. Res. Inst., Agric. Res. Cent., Dokki, Egypt
}

Received: 08/02/2017 ; Accepted: 16/03/2017

\begin{abstract}
The effect of high hydrostatic pressure (HHP) treatments on chemical composition, proteolysis, rheological properties, total free amino acids and organoleptic properties for Cheddar cheese during ripening at $8-10^{\circ} \mathrm{C}$ up to 120 days were evaluated. Application of HHP-treated Cheddar cheese at three levels $\left(200,400\right.$ and $600 \mathrm{MPa}$ at $25^{\circ} \mathrm{C}$ for $20 \mathrm{~min}$.) was carried out as a methods for acceleration of Cheddar cheese ripening. Results showed that HHP-treated at $600 \mathrm{MPa}$ for $20 \mathrm{~min}$. at $25^{\circ} \mathrm{C}$ was significantly higher in moisture, fat in dry matter and $\mathrm{pH}$ values, on the other hand total solids, was significantly lower throughout the ripening period followed by cheeses treated at 400, 200 $\mathrm{MPa}$ for $20 \mathrm{~min}$. and control cheeses, respectively. All Cheddar cheeses treated with HHP showed significant $(\mathrm{P} \geq 0.05)$ higher increase in nitrogen fractions (WSN/TN\% and NPN/TN\%) than control cheese during ripening up to 120 days. Morover, total volatile fatty acids was significantly higher $(\mathrm{P} \geq 0.05)$ in cheese treated at $600 \mathrm{MPa}$ than other cheeses during ripening. Rheological properties indicated that, HHP-treated Cheddar cheese at $600 \mathrm{MPa}$ for $20 \mathrm{~min}$. The significant lower $(\mathrm{P} \geq 0.05)$ values of hardness as compared to cheese treated at 200, $400 \mathrm{MPa}$ and control cheeses. lowest values of chewiness and gumminess were observed in cheese treated at 200 and $400 \mathrm{MPa}$ at the end of ripening. Also, HHP-treated Cheddar cheese at $600 \mathrm{MPa}$ had a higher levels of total free amino acids than other cheeses treated at 200, $400 \mathrm{MPa}$ and control cheeses,. HHP-treated Cheddar cheeses gained significantly higher flavour and texture scores compared to control cheese, but HHP-treated Cheddar chees at $600 \mathrm{MPa}$ for $20 \mathrm{~min}$. showed higher total scores than other cheese treatments.
\end{abstract}

Key words: High hydrostatic pressure (HHP), Cheddar cheese, cheese ripening, ripening indices, rheological properties.

\section{INTRODUCTION}

Cheese ripening involves several biochemical processes including proteolysis, lipolysis and glycolysis. Proteolysis is the principal and most complex biochemical event occurring during ripening process of most cheese varieties. Proteolysis contributes to cheese ripening through a direct contribution to flavour via the formation of peptides and amino acids, and changing the texture of cheese owing

\footnotetext{
*Corresponding author: Tel. : +201065024953

E-mail address: draliabdelgaleel@yahoo.com
}

to breakdown of the protein network (Fox and Wallace, 1997). The mechanism by which such acceleration is achieved remains unclear, but may well involve effects on starter bacteria in cheese. HHP treatment causes perturbation of bacteria cell walls and membranes. Therefore, it is possible that exposure of starter cell to HP may cause the cells to autolysis and release intracellular enzymes. Among the modern technologies in the food industry, the most important are those involving non-thermal 
treatment of the products. High pressure (HP) processing (100-1000 MPa) is one of the most promising methods for the food treatment and preservation at room temperature (Cheftel, 1995) and of great concern because of its potential to achieve interesting functional effects. There are numerous areas of interest regarding the HP processing of cheese, the more important including cheese making from HPtreated milk, acceleration of cheese ripening and inactivation or reduction of pathogenic or spoilage microorganism in cheese to increase cheese safety and shelf life (Trujillo et al., 2002). A patent by Yokoyama et al. (1992) describes a method for shortening ripening by application of high hydrostatic pressure (HHP) in association with a highly proteolytic starter and exogenous enzymes. Jin and Harper (1996) described a method for reliable acceleration of ripening of cheese slurries by using HHP to maintain undesirable microorganisms under control, these enhancing flavour development. In Hispanico cheese manufacture from mixture of cow's and ewe's milk, HP treatment at 400 $\mathrm{MPa}$ for $5 \mathrm{~min}$. accelerated the hydrolysis of casein and increased the TFVA content, but did not influence the taste quality and flavour intensity of the cheese (Avila et al., 2006). It is possible that HP treatment applied on the first day of ripening affected the enzymes involved in amino acids biochemistry and subsequent compound formations in cheese. Cheese treated at $300 \mathrm{MPa}$ at day one was defined as the most elastic and least crumbly cheese, which could be explained by changes in the casein network and the water content. HHP treatment of cheese had focused on acceleration of cheese through ripening changes in enzymatic activity during ripening (Yokoyama et al., 1992). Biochemical reactions may be influenced by HHP by means of the effect on volume changes involved in the reaction or by the direct affect of HHP on enzymes. HHP produces conformational changes in protein, and some changes may effect enzyme modulation sites or active sites directly (Rover, 1995). Acceleration of the ripening step of cheese production is an area of scientific and commercial interest. Accelerating ripening allow to reduce the financial cost of maintaining a large stock of cheese for long period. Acceleration of Cheddar cheese ripening is of major commercial interest, as decreased storage times offer significant economic gain (Fox et al., 1996). Starter bacteria are one of the primary sources of ripening enzymes. However, many starter enzymes (proteinases and peptidases) required for proteolysis are intracellular and autolysis of starter bacteria is required for their liberation (Tomas and Prichard, 1987). Increasing the autolysis rate of starter culture cells increases rates of proteolysis in cheese (Crow et al., 1995). A number of reports have indicated that application of high pressure (HP) can accelerate cheese ripening, in particular proteolysis (Messens et al., 1999; Saldo et al., 2000; Trujillo et al., 2000 ; O'Reilly et al., 2001).

The aim of the current work is to study the effect of HHP treatment at different levels. On the main compositional, proteolysis, rheological properties and sensory characteristics in Cheddar cheese, during ripening period.

\section{MATERIALS AND METHODS}

\section{Cheese Manufacture and High Pressure Treatment}

Four independent batches of Cheddar cheese were manufactured from pasteurized cows' milk at $72^{\circ} \mathrm{C} / 15$ sec., obtained from Washington Stat University Creamery. Cheddar cheese was made in duplicate using the method described by Kosikowski (1982). The cheese was cut into 500 $\mathrm{g}$ blocks of equal dimensions $(6 \times 6 \times 11 \mathrm{~cm})$ which were placed in polyethylene bags and vacuum packaged. Cheeses were HHP-treated by using a Quintus High pressure Food Processor (Engineered system, Inc. Andover, MA, USA). The one day old cheeses were subjected to pressures at 0 (control), 200, 400 and $600 \mathrm{MPa}$ for $20 \mathrm{~min}$. at $25 \pm 4^{\circ} \mathrm{C}$. Cheeses were placed at $10^{\circ} \mathrm{C}$ immediately after pressure treatment and stored at the same temperature during ripening period for 120 days. Cheese samples were analyzed when fresh (first day then after pressure treatment), 30, 60, 90 and 120 days. 


\section{Chemical Composition}

HHP-treated cheese samples were analyzed for moisture, protein, fat, acidity and $\mathrm{pH}$ using standard procedures (Marshall, 1992). The levels of soluble nitrogen (SN) and non protein nitrogen (NPN) contents in cheese were determined as described by Rynne et al. (2004).The total volatile fatty acids (TVFA) were determined by the distillation method of Kosikowski (1982).

\section{Determination of Free Amino Acids}

Free amino acids were determined (as $\mathrm{mg} /$ $100 \mathrm{~g}$ cheese) by using LC3000 Amino Acids Analyzer, Eppendrof-Germany as described by Mondino et al. (1972). Conditions: Flow rate: $0.2 \mathrm{ml} / \mathrm{min}$. Pressure of buffer form 0 to 50 bar. Pressure of reagent to $0-150$ bar. Reaction temperature $123^{\circ} \mathrm{C}$.

\section{Measurement of Texture Properties}

Texture profile analyses of cheeses were done using the double compression test (TAXT2 texture analyzer, Stable Micro System, Biological Systems Engineering, WSU, USA). Ten cylindrical portions $(1 \mathrm{~cm}$ high $\times 1 \mathrm{~cm}$ diameter) were removed from the interior of the cheese samples with a cork borer held at room temperature for $1 \mathrm{hr}$., before testing. Cylinders were compressed to $80 \%$ of their original height and the compressed speed was set at $2 \mathrm{~cm} \mathrm{~min}^{-1}$. The following parameters were evaluated according to the definitions given by the IDF (1991). Hardness was defined as the force required for compressing the cheese sample to $80 \%$ of its original height during the first compression cycle. Cohesiveness was defined as the ratio of the area under the positive region (during application of force) of the second compression curve to that of the first compression curve. Springiness was defined as the ratio of the time taken to compress the sample to $80 \%$ of its original height during the second compression cycle to that of the first compression cycle. Chewiness was defined as the product of gumminess and springiness, where gumminess is defined as the product of harness and cohesiveness. Equipment availability required the change in the last sampling day for texture analysis.

\section{Sensory Evaluation}

Control and experimental cheeses were organoleptically evaluated when fresh, and then after 30,60, 90 and 120 days of storage. Cheeses were coded and removed from refrigerator $\left(10^{\circ} \mathrm{C}\right) 1 \mathrm{hr}$., prior to evaluation, kept at room temperature $\left(22 \pm 1{ }^{\circ} \mathrm{C}\right)$, Cheese samples when fresh and during storage period were scored for flavour (50 Point), body and texture (40 Point) and appearance (10 Point) by regular score panels of the staff members of the dairy department . (Muir et al., 1996)

\section{Statistical Analysis}

The statistical analysis was computed using analysis of variance procedures. Significant $(\mathrm{P} \geq 0.05)$ differences between means were determined by Duncan $\mathrm{s}$ Multiple Rang test procedures described in SAS (2003).

\section{RESULTS AND DISCUSSION}

\section{Effect of HHP-Treatment on Cheese Composition}

Results presented in Table 1 indicate that HHP-treatments of Cheddar cheese significantly $(\mathrm{P} \geq 0.05)$ increased the moisture contents, fat on dry matter and $\mathrm{pH}$ values in resultant cheese compared with control cheese during storage period. However, cheese treated with $600 \mathrm{MPa}$ for $20 \mathrm{~min}$. had significantly higher moisture content throughout ripening period than other cheeses treated with HHP and control cheese. Also, these results shows that, moisture contents decreased, but fat on dry matter and $\mathrm{pH}$ values gradually increased with the advanced of storage period in all treatments. The higher moisture content for HHP treated cheeses was also observed in previous studies and high water retention ability seems to be related to a change in the structure of the para-casainate network (Saldo et al., 2000 and 2002). These fildings were in agreement with these reported by Daniela (2010, 2011 and 2012). 
The increase in $\mathrm{pH}$ value of HHP-treated cheese could be related to the decrease in the starter counts observed after HHP treatment (Saldo et al., 2002; Juan et al., 2007 and 2007 ; Bibiana et al., 2008). These results agree with that reported by Darke et al. (1997) in Cheddar cheese and Trujillo et al. (1999) in goat's milk cheese. They found that cheeses mad from HHP-milk cheese presented a higher moisture content than raw milk and pasteurized milk cheeses and this was responsible for significant higher yield, and pressure treatment of milk lead to greater moisture retention, due to the fact that denatured protein (especially $\beta$-lactoglobiuline) are incorporated in cheese.

\section{Ripening Indices}

Results presented in Table 2 indicate that, HHP-treated Cheddar cheese showed significant $(\mathrm{P} \geq 0.05)$ higher soluble nitrogen on total nitrogen ( $\mathrm{SN} / \mathrm{TN} \%$ ), non-protein nitrogen on total nitrogen (NPN/TN\%) and total volatile fatty acids (TVFA) at the different stages of ripening period compared with control cheese. All cheeses showed a higher increase in (SN/TN\%), and (NPN/TN\%) as ripening period progressed. The $600 \mathrm{MPa}$-treated Cheddar cheese showed significant higher levels of the soluble nitrogenous compound (SN/TN and NPN/TN) compared with other treated and control cheese. These results suggested that 600 $\mathrm{MPa}$ treatment causes enzyme releasing that accelerate ripening of cheese. This could be explained on the basis that, hydrolysis of $\beta$ casein was significantly higher in HHP-treated cheeses than control cheese. An increase of hydrolysis of $\beta$-casein was observed in Cheddar cheese treated at $200-400 \mathrm{MPa}$ at $25^{\circ} \mathrm{C}$ for 20 min. (O'Reilly et al., 2002), Also, in ewe's milk cheese treated at $200-500 \mathrm{MPa}$ at $10^{\circ} \mathrm{C}$ for 10 min. (Juan et al., 2007a). Also, The results in the present work are in agreement with that reported by Messens et al. (1998) they investigated the use of HP to accelerate the ripening in Gouda-type cheese, pressures and times used in their study ranged from 100-400 $\mathrm{MPa}$ and from 0.5 to $4 \mathrm{hr}$., respectively. They reported that the higher pressure used at 300 $\mathrm{MPa} / 50 \mathrm{~min}$. caused the disruption of the paracasein network leading to higher amount of peptides and proteins especially $\beta$-casein (Saldo et al., 2000 and 2002; Gard et al., 2007; Juan et al., 2007b). Similar results were recorded by Daniela (2011 and 2012)

Also, Table 2 shows that the total volatile fatty acids (TVFAs) levels in HHP-treated Cheddar cheeses were higher $(\mathrm{P} \geq 0.05)$ than control cheese. Cheddar cheeses treated at 600 $\mathrm{MPa}$ for $20 \mathrm{~min}$. had a higher significantly $(\mathrm{P} \geq 0.05)$ than cheeses-HHP treated at 400,200 $\mathrm{MPa}$ and control one. This might be due to faster and better interaction of microbial lipases with the substrate due to the lysis produced by HHP treatment. These results are in agreement with those reported by (McSweeny and Sousa, (2000). They found that ewes' milk cheese HPrteated at 200-500 $\mathrm{MPa}$ on days 1 and 15 of ripening, -cheeses showed the highest degree of lipolysis, which was attributed to the faster and better interaction of microbial lipases with substrate. Also, Juan et al., (2007b) reported that higher amounts of ethyl esters were found in ewes' milk cheese HP-treated at $300 \mathrm{MPa}$ on the first day of ripening compared with those treated at 15 days of ripening and untreated cheese.

\section{Free Amino Acids}

Results presented in Table 3 shows that the total levels of free amino acids (FAAs) of HHPtreated Cheddar cheese increased in all cheeses with the progress of the storage period, HHPtreated Cheddar cheese on one day resulted in higher total levels of free amino acids in fresh, 90 and 120 days old cheese compared to control cheeses. These results are in agreement with that reported by Gard et al. (2007).

The increase in total levels of FAAs in cheese treated with HHP was related to its higher amino peptedase activity values than control cheese (Juan et al., 2007b). Also, these increasing in total levels of FAAs may be due to the release of peptidase to cheese matrix after the lysis of starter cells, The higher $\mathrm{pH}$ values HHP-treated cheeses and perhaps confermetical changes in peptides structures rendering them more susceptible to the action of peptidase, this may be explain the higher content of total FAAs in experimental cheeses than control cheese (O’Reilly et al., 2002 ; Gard et al., 2007). 
Zagazig J. Agric. Res., Vol. 44 No. (2) 2017

Table 1. Chemical composition of Cheddar cheese as affected by using different levels of high hydrostatic pressure (HHP)-treatments for $20 \mathrm{~min}$.

\begin{tabular}{|c|c|c|c|c|c|c|}
\hline \multirow[t]{2}{*}{$\overline{\text { Cheese property }}$} & \multirow{2}{*}{$\begin{array}{c}\text { Storage period } \\
\text { (day) }\end{array}$} & \multirow[t]{2}{*}{ Control } & \multicolumn{3}{|c|}{ HHP-treatment for $20 \mathrm{~min}$. } & \multirow[t]{2}{*}{ Sig. } \\
\hline & & & $200 \mathrm{Mpa}$ & 400 Мра & $600 \mathrm{Mpa}$ & \\
\hline \multirow{5}{*}{ Total solids (\%) } & 0 & $66.25^{\mathrm{a}}$ & $65.90^{b}$ & $65.65^{c}$ & $65.60^{\mathrm{c}}$ & $* * *$ \\
\hline & 30 & $67.10^{\mathrm{a}}$ & $66.55^{\mathrm{b}}$ & $66.34^{\mathrm{c}}$ & $66.28^{\mathrm{c}}$ & $* * *$ \\
\hline & 60 & $67.44^{\mathrm{a}}$ & $67.30^{\mathrm{b}}$ & $67.13^{c}$ & $67.04^{\mathrm{d}}$ & $* * *$ \\
\hline & 90 & $68.85^{\mathrm{a}}$ & $68.67^{\mathrm{b}}$ & $68.50^{\mathrm{c}}$ & $68.27^{\mathrm{d}}$ & $* * *$ \\
\hline & 120 & $69.00^{\mathrm{a}}$ & $68.85^{\mathrm{b}}$ & $68.77^{\mathrm{b}}$ & $68.60^{c}$ & $* * *$ \\
\hline \multirow{5}{*}{ Moisture (\%) } & 0 & $33.75^{\mathrm{c}}$ & $34.10^{\mathrm{b}}$ & $34.35^{\mathrm{a}}$ & $34.40^{\mathrm{a}}$ & $* * *$ \\
\hline & 30 & $32.90^{\mathrm{c}}$ & $33.45^{b}$ & $33.66^{\mathrm{a}}$ & $33.72^{\mathrm{a}}$ & $* * *$ \\
\hline & 60 & $32.56^{\mathrm{d}}$ & $32.70^{\mathrm{c}}$ & $32.87^{b}$ & $32.96^{\mathrm{a}}$ & $* * *$ \\
\hline & 90 & $31.15^{\mathrm{d}}$ & $31.33^{\mathrm{c}}$ & $31.50^{\mathrm{b}}$ & $31.73^{\mathrm{a}}$ & $* * *$ \\
\hline & 120 & $31.00^{\mathrm{c}}$ & $31.15^{\mathrm{b}}$ & $31.23^{b}$ & $31.40^{\mathrm{a}}$ & $* * *$ \\
\hline \multirow{5}{*}{ Fat / D.M (\%) } & 0 & $48.60^{\mathrm{c}}$ & $49.35^{\mathrm{b}}$ & $51.15^{\mathrm{a}}$ & $51.23^{\mathrm{a}}$ & $* * *$ \\
\hline & 30 & $50.25^{d}$ & $50.47^{\mathrm{c}}$ & $51.64^{b}$ & $51.77^{\mathrm{a}}$ & $* * *$ \\
\hline & 60 & $51.33^{c}$ & $51.60^{b}$ & $52.10^{\mathrm{a}}$ & $52.18^{a}$ & $* * *$ \\
\hline & 90 & $52.40^{\mathrm{d}}$ & $52.75^{\mathrm{c}}$ & $52.96^{\mathrm{b}}$ & $53.05^{\mathrm{a}}$ & $* * *$ \\
\hline & 120 & $52.60^{d}$ & $52.86^{\mathrm{c}}$ & $53.15^{b}$ & $53.32^{\mathrm{a}}$ & $* * *$ \\
\hline \multirow{5}{*}{ pH } & 0 & $5.24^{\mathrm{a}}$ & $5.25^{\mathrm{a}}$ & $5.27^{\mathrm{a}}$ & $5.27^{\mathrm{a}}$ & NS \\
\hline & 30 & $5.13^{\mathrm{b}}$ & $5.15^{b}$ & $5.18^{\mathrm{a}}$ & $5.19^{\mathrm{a}}$ & ** \\
\hline & 60 & $5.06^{\mathrm{b}}$ & $5.09^{a b}$ & $5.12^{\mathrm{a}}$ & $5.14^{\mathrm{a}}$ & $*$ \\
\hline & 90 & $5.01^{\mathrm{c}}$ & $5.05^{\mathrm{b}}$ & $5.07^{\mathrm{ab}}$ & $5.09^{\mathrm{a}}$ & ** \\
\hline & 120 & $5.00^{\mathrm{a}}$ & $5.03^{\mathrm{a}}$ & $5.04^{\mathrm{a}}$ & $5.06^{\mathrm{a}}$ & NS \\
\hline
\end{tabular}

$\mathrm{a}, \mathrm{b}, \mathrm{c}, \mathrm{d}=$ Means having different letters in the same raw significantly differed at $\mathrm{p} \geq 0.05$.

LSD $=$ Least significant difference

$*=$ Significant $\quad * *=$ High significant $\quad * * *=$ Very high significant $\quad$ NS=Not significant

Table 2. Ripening Indices of Cheddar cheese as affected by using different levels of high hydrostatic pressure (HHP)-treatments for $20 \mathrm{~min}$.

\begin{tabular}{|c|c|c|c|c|c|c|}
\hline \multirow[t]{2}{*}{ Cheese property } & \multirow{2}{*}{$\begin{array}{c}\text { Storage period } \\
\text { (day) }\end{array}$} & \multirow[t]{2}{*}{ Control } & \multicolumn{3}{|c|}{ HHP treatment for $20 \mathrm{~min}}$. & \multirow[t]{2}{*}{ Sig. } \\
\hline & & & 200 Мра & 400 Мра & 600 Мра & \\
\hline \multirow[t]{5}{*}{ SN/TN (\%) } & 0 & $4.37^{\mathrm{a}}$ & $4.39^{\mathrm{a}}$ & $4.42^{\mathrm{a}}$ & $4.44^{\mathrm{a}}$ & NS \\
\hline & 30 & $10.76^{\mathrm{c}}$ & $10.84^{\mathrm{b}}$ & $10.89^{b}$ & $10.98^{\mathrm{a}}$ & $* *$ \\
\hline & 60 & $13.22^{\mathrm{d}}$ & $13.51^{\mathrm{c}}$ & $13.66^{\mathrm{b}}$ & $13.85^{\mathrm{a}}$ & *** \\
\hline & 90 & $16.65^{\mathrm{d}}$ & $17.10^{\mathrm{c}}$ & $17.32^{\mathrm{b}}$ & $17.43^{\mathrm{a}}$ & $* * *$ \\
\hline & 120 & $18.70^{d}$ & $19.45^{\mathrm{c}}$ & $19.67^{b}$ & $19.92^{\mathrm{a}}$ & **** \\
\hline \multirow[t]{5}{*}{ NPN/TN (\%) } & 0 & $2.24^{\mathrm{a}}$ & $2.26^{\mathrm{a}}$ & $2.28^{\mathrm{a}}$ & $2.29^{\mathrm{a}}$ & NS \\
\hline & 30 & $3.85^{\mathrm{d}}$ & $3.98^{\mathrm{c}}$ & $4.17^{b}$ & $4.28^{\mathrm{a}}$ & *** \\
\hline & 60 & $5.78^{d}$ & $5.93^{\mathrm{c}}$ & $6.09^{b}$ & $6.21^{\mathrm{a}}$ & $* * *$ \\
\hline & 90 & $7.95^{\mathrm{d}}$ & $8.43^{\mathrm{c}}$ & $8.61^{b}$ & $8.85^{\mathrm{a}}$ & *** \\
\hline & 120 & $9.30^{d}$ & $10.15^{\mathrm{c}}$ & $10.33^{b}$ & $10.46^{\mathrm{a}}$ & **** \\
\hline \multirow[t]{2}{*}{ TVFA } & 0 & $11.63^{c}$ & $11.70^{\mathrm{bc}}$ & $11.85^{\mathrm{ab}}$ & $11.96^{\mathrm{a}}$ & $* *$ \\
\hline & 30 & $14.30^{\mathrm{d}}$ & $14.56^{\mathrm{c}}$ & $14.88^{b}$ & $15.12^{\mathrm{a}}$ & $* * *$ \\
\hline ml $0.1 \mathrm{~N}$ & 60 & $20.76^{\mathrm{d}}$ & $20.96^{\mathrm{c}}$ & $22.25^{\mathrm{b}}$ & $21.50^{\mathrm{a}}$ & *** \\
\hline \multirow[t]{2}{*}{ Naoh/100g } & 90 & $25.00^{\mathrm{d}}$ & $26.15^{\mathrm{c}}$ & $26.57^{b}$ & $26.98^{\mathrm{a}}$ & $* * *$ \\
\hline & 120 & $28.31^{\mathrm{d}}$ & $28.85^{\mathrm{c}}$ & $29.16^{\mathrm{b}}$ & $29.56^{\mathrm{a}}$ & $* * *$ \\
\hline
\end{tabular}

$\mathrm{a}, \mathrm{b}, \mathrm{c}, \mathrm{d}=$ Means having different letters in the same raw significantly differed at $\mathrm{p} \geq 0.05$.

LSD $=$ Least significant difference

*=Significant $\quad * *=$ High significant $\quad * * *=$ Very high significant $\quad$ NS=Not significant 
Table 3. Free amino acids of Cheddar cheese as affected by using different levels of high hydrostatic pressure (HHP)-treatments for 20 min.

\begin{tabular}{|c|c|c|c|c|c|c|c|c|c|c|c|c|}
\hline \multirow{3}{*}{$\begin{array}{l}\text { Amino acid } \\
\text { (mg/ } 100 \mathrm{~g})\end{array}$} & \multirow{2}{*}{\multicolumn{3}{|c|}{ Control }} & \multicolumn{9}{|c|}{ HHP - treatment for $20 \mathrm{~min}$} \\
\hline & & & & \multicolumn{3}{|c|}{200 Мра } & \multicolumn{3}{|c|}{400 Мра } & \multicolumn{3}{|c|}{600 Мра } \\
\hline & $\mathbf{0}$ & 90 & 120 & $\mathbf{0}$ & 90 & 120 & $\mathbf{0}$ & 90 & 120 & $\mathbf{0}$ & 90 & 120 \\
\hline Aspartic & 15.10 & 25.23 & 28.15 & 19.52 & 37.30 & 29.12 & 24.96 & 31.56 & 37.56 & 23.61 & 32.25 & 37.00 \\
\hline Thereonine & 7.23 & 15.32 & 10.44 & 11.33 & 22.14 & 17.31 & 13.10 & 16.85 & 22.53 & 14.42 & 18.43 & 25.21 \\
\hline Serine & 9.81 & 19.07 & 19.72 & 15.10 & 29.76 & 22.10 & 18.35 & 22.84 & 28.47 & 18.45 & 24.30 & 29.24 \\
\hline Glutamic & 45.36 & 61.46 & 87.18 & 52.30 & 85.41 & 92.35 & 78.12 & 94.25 & 93.88 & 60.57 & 83.71 & 95.80 \\
\hline Glycine & 2.45 & 5.51 & 5.23 & 6.64 & 12.40 & 6.11 & 4.13 & 6.17 & 8.15 & 5.32 & 6.91 & 8.53 \\
\hline Alanine & 4.62 & 15.54 & 15.10 & 9.98 & 18.83 & 17.06 & 11.09 & 18.26 & 23.49 & 14.33 & 19.35 & 24.16 \\
\hline Valine & 9.25 & 17.10 & 17.46 & 14.81 & 27.92 & 17.75 & 14.17 & 21.10 & 25.20 & 18.86 & 23.27 & 30.65 \\
\hline Methionine & 6.70 & 12.96 & 11.48 & 8.83 & 17.44 & 15.21 & 11.30 & 16.15 & 19.65 & 12.64 & 18.72 & 20.48 \\
\hline Isoleucine & 9.86 & 15.33 & 16.91 & 11.74 & 22.66 & 18.53 & 14.55 & 20.23 & 23.81 & 17.85 & 22.10 & 27.44 \\
\hline Leucine & 30.84 & 34.25 & 40.75 & 26.15 & 50.87 & 43.66 & 35.48 & 47.61 & 53.84 & 35.41 & 45.83 & 53.46 \\
\hline Tyrosine & 23.63 & 31.66 & 40.50 & 20.77 & 38.25 & 44.13 & 21.44 & 37.42 & 49.11 & 31.60 & 39.41 & 48.25 \\
\hline Phenyl alanine & 21.07 & 30.73 & 30.94 & 23.26 & 42.10 & 35.54 & 27.61 & 35.00 & 46.53 & 29.08 & 21.66 & 47.24 \\
\hline Histidine & 26.54 & 24.80 & 20.41 & 18.71 & 29.96 & 27.98 & 30.26 & 26.74 & 38.27 & 23.30 & 21.21 & 32.00 \\
\hline Lysine & 31.05 & 29.27 & 31.17 & 23.50 & 45.70 & 39.11 & 31.32 & 39.05 & 44.86 & 30.12 & 39.40 & 45.73 \\
\hline $\mathrm{NH}_{4}^{+}$ & 18.11 & 31.84 & 66.72 & 26.53 & 48.97 & 72.33 & 52.48 & 51.77 & 49.18 & 35.22 & 45.43 & 44.37 \\
\hline Arginine & 19.88 & 17.15 & 15.24 & 12.88 & 23.25 & 13.41 & 15.75 & 21.50 & 25.20 & 18.65 & 24.43 & 31.36 \\
\hline proline & 210.13 & 378.20 & 442.80 & 282.41 & 278.86 & 492.75 & 317.30 & 481.72 & 580.43 & 373.88 & 507.16 & 604.87 \\
\hline Total & 491.63 & 765.42 & 903.20 & 584.46 & 831.82 & 1004.45 & 721.41 & 988.22 & 1170.16 & 763.31 & 993.57 & 1205.79 \\
\hline
\end{tabular}

On the other hand, the results in the same Table showed remarkable increasing of proline, leuccine, tyrosine, phenylalanine, histidine and lysine in all treatments during ripening period. Generally, HHP-treated Cheddar cheeses showed higher concentration of these previous FAAs than control cheese. But Cheddar cheese treated at $600 \mathrm{MPa}$ for $20 \mathrm{~min}$. had the highest level of total FAAs than other treatments and control cheeses. These results are in accordance with those reported by McSweeny and Sousa (2000). Upadhyay et al. (2007) who found that TFAAs is an index of the proteolytic enzymes activity produced by starter lactic acid bacteria, mainly those hydrolyze small peptides to produce free amino acids. These phenomemenan are in agreement with that obtained by Trujillo et al. (1999) and Gard et al. (2007) who found that the increasing in total levels of free amino acids for semi-hard ewe's cheese treated with $\mathrm{HHP}$ at $\left(300 \mathrm{MPa}\right.$ at $25^{\circ} \mathrm{C}$ for $10 \mathrm{~min}$.) than control cheeses may be due to that HHPtreatment cause the release enzymes through the lysis of starter cell. The results obtained in the current study agree with that reported by Saldo et al. (2002) who found that overall application of at the high pressure of beginning of ripening significantly increased secondary proteolysis or conversion of peptides into free amino acids. The use of high pressure treated Cheddar cheese generally accelerated the liberation of most of the amino acids compared to control, including some of the major amino acids which dominated FAA profile of Cheddar cheese are. FAAs in cheese precursors for many catabolic reaction that results in volatile and sapid compounds (Curtin and McSweeny, 2004).

Accelerated liberation of most amino acids in cheeses manufacture using high pressure treated starter culture may promote increased production of volatile compounds and influence the flavour of cheese (Fox and Wallace, 1997; 
Saldo et al., 2002 ; Trujillo et al., 2002). However, Upadhyay et al. (2007) studied the effect of HP-treated Cheddar cheese at (200MPa for $20 \mathrm{~min}$. at $20^{\circ} \mathrm{C}$ ) as all as attenuate starters bacteria for use as adjusts also HP-treated Cheddar cheese generally had higher levels of free amino acids, The differences in the levels of free amino acids in cheese treated with HP when different starters were used can be attributed to different rates of lysis of starter cells in cheese matrix and different in types and levels of enzymes from the strains. Finally, pressure treated at 200, 400 and $600 \mathrm{MP}$ at $25^{\circ} \mathrm{C}$ for 20 min. for Cheddar cheese significantly increased levels of proteolysis during ripening compared to control cheese. However, the exposure at 600 $\mathrm{MPa}$ for $20 \mathrm{~min}$. was sufficient to enhance levels of proteolysis and total levels of free amino acids.

\section{Rheological Properties}

Texture profile analysis (TPA) parameters calculated for TPA analysis for the control and pressure-treated Cheddar cheese samples are shown in Table 4. It is evident that control and treated cheeses at different levels of HHP (200, 400 and $600 \mathrm{MPa}$ for $20 \mathrm{~min}$.) revealed significantly differences for texture characteristic such as (Hardness, Adhesiveness, Cohesiveness, Springiness, Gumminess, Chewiness and Rezilince) during ripening up to 120 days.

Hardiness of control and pressure-treated Cheddar cheese decreased gradually during ripening. However, on one day, all pressuretreated Cheddar cheeses were softer than control cheese. Cheddar cheese treated at $600 \mathrm{MPa}$ for $20 \mathrm{~min}$. showed much lower values of hardiness as compared with $200,400 \mathrm{MPa}$ and control cheese during ripening.

The hardiness of HHP-treated cheese was significantly lower $(p \geq 0.05)$ than control cheese up to 120 days. This may be mainly due to proteolysis of casein to small compounds which are very soluble in water. The correlation between texture properties and the proteolysis indices are in agreement with the results given by El-Zeini et al. (2007). However, McSweeny and Fox (1997) reported that for most cheese varietie, proteolysis is the most commonly used as index of maturity and it is though that the break down of $\alpha \mathrm{s}_{1}$ casein is the most significant reaction responsible for the initial softening of cheese body and texture indicating that textural changes during ripening are related to proteolysis.

In Cheddar cheese HHP of 50 Mpa treatment for 3 days (O'Reilly et al., 2000) and $400-500$ Mpa for 5 min., (Nienaber and Shellhammer, 2000) increased softening of cheeses.

Also, Adhesiveness was positively correlated with moisture, however negative correlation was found between the adhesiveness and fat, $\mathrm{pH}$ and TVFA. Adhesiveness in all cheeses decreased during ripening and it was significantly lower values $(\mathrm{p} \geq 0.05)$ in Cheddar cheese treated at 400 $\mathrm{MPa}$ for $20 \mathrm{~min}$. than $200,600 \mathrm{MPa}$ for $20 \mathrm{~min}$. and control cheeses respectively. The control samples had the lowest moisture content and highest hardiness and Springiness during storage, while the cheeses treated at 200, 400 and $600 \mathrm{MPa}$ for $20 \mathrm{~min}$. showed the lowest levels of Springiness. All cheeses treated with HHP showed just significantly ( $\mathrm{p} \geq 0.05$ ) during ripening compared to control. Working with goat's milk cheese found that calcium-caseinat was disrupted under high pressure become calcium migrates to the soluble phase.

The Cohesiveness of untreated samples decreased after 60 days, while cheese treated with HHP showed slightly significant differences $(p \geq 0.05)$ after 60 days of ripening. The Cohesiveness for all pressure treated cheeses samples on 60 days was lower than on one day, but significantly higher than for untreated samples. These results are in agree with that reported by Saldo et al. (2001) and Iazmin et al. (2005).

HHP cheese treated at $400 \mathrm{MPa}$ for $20 \mathrm{~min}$. showed lower values of Chewiness and Gumminess than other treatments and control samples. It is obvious from those results that Chewiness and Gumminess were slightly decreased $(\mathrm{p} \geq 0.05)$ in all treatments during ripening compared with control which showed significantly higher values during ripening. These may be due to progressive increase in the Hardiness, Cohesiveness and Springiness. These results are in accordance with those reported by Awad et al. (2005). Cohesiveness, Gumminess and Chewiness were differed significantly $(\mathrm{p} \geq 0.05)$. 
Table 4. Rheological properties of Cheddar cheese as affected by using different levels of high hydrostatic pressure (HHP)-treatments for $20 \mathrm{~min}$.

\begin{tabular}{|c|c|c|c|c|c|c|}
\hline \multirow[t]{2}{*}{ Cheese property } & \multirow{2}{*}{$\begin{array}{c}\text { Storage period } \\
\text { (day) }\end{array}$} & \multirow[t]{2}{*}{ Control } & \multicolumn{3}{|c|}{ HHP treatment for 20 min. } & \multirow[t]{2}{*}{ Sign. } \\
\hline & & & $200 \mathrm{Mpa}$ & 400 Мра & $600 \mathrm{Mpa}$ & \\
\hline \multirow{5}{*}{ Hardness } & 0 & $25.42^{\mathrm{a}}$ & $20.53^{\mathrm{b}}$ & $13.81^{\mathrm{d}}$ & $14.84^{\mathrm{c}}$ & $* * *$ \\
\hline & 30 & $19.72^{\mathrm{a}}$ & $17.74^{\mathrm{b}}$ & $13.00^{\mathrm{c}}$ & $13.20^{\mathrm{c}}$ & $* * *$ \\
\hline & 60 & $19.10^{\mathrm{a}}$ & $14.59^{b}$ & $12.80^{\mathrm{d}}$ & $12.94^{\mathrm{c}}$ & $* * *$ \\
\hline & 90 & $16.20^{\mathrm{a}}$ & $14.56^{\mathrm{b}}$ & $12.00^{\mathrm{c}}$ & $12.23^{\mathrm{c}}$ & $* * *$ \\
\hline & 120 & $16.00^{\mathrm{a}}$ & $14.51^{b}$ & $11.95^{\mathrm{c}}$ & $12.05^{\mathrm{c}}$ & $* * *$ \\
\hline \multirow{5}{*}{ Adhesiveness } & 0 & $0.53^{\mathrm{a}}$ & $0.47^{\mathrm{a}}$ & $0.45^{\mathrm{a}}$ & $0.48^{\mathrm{a}}$ & NS \\
\hline & 30 & $0.38^{\mathrm{a}}$ & $0.33^{\mathrm{a}}$ & $0.34^{\mathrm{a}}$ & $0.43^{\mathrm{a}}$ & NS \\
\hline & 60 & $0.21^{\mathrm{b}}$ & $0.21^{\mathrm{b}}$ & $0.30^{\mathrm{ab}}$ & $0.38^{\mathrm{a}}$ & $*$ \\
\hline & 90 & $0.18^{\mathrm{b}}$ & $0.16^{\mathrm{b}}$ & $0.29^{\mathrm{a}}$ & $0.25^{\mathrm{a}}$ & $* *$ \\
\hline & 120 & $0.13^{b}$ & $0.12^{\mathrm{b}}$ & $0.26^{\mathrm{a}}$ & $0.20^{\mathrm{ab}}$ & $*$ \\
\hline \multirow{5}{*}{ Springiness } & 0 & $0.74^{\mathrm{a}}$ & $0.68^{\mathrm{a}}$ & $0.69^{\mathrm{a}}$ & $0.67^{\mathrm{a}}$ & NS \\
\hline & 30 & $0.69^{\mathrm{a}}$ & $0.65^{\mathrm{a}}$ & $0.67^{\mathrm{a}}$ & $0.65^{\mathrm{a}}$ & NS \\
\hline & 60 & $0.68^{\mathrm{a}}$ & $0.64^{\mathrm{a}}$ & $0.66^{\mathrm{a}}$ & $0.64^{\mathrm{a}}$ & NS \\
\hline & 90 & $0.66^{\mathrm{a}}$ & $0.63^{\mathrm{a}}$ & $0.64^{\mathrm{a}}$ & $0.62^{\mathrm{a}}$ & NS \\
\hline & 120 & $0.63^{\mathrm{a}}$ & $0.60^{\mathrm{a}}$ & $0.61^{\mathrm{a}}$ & $0.59^{\mathrm{a}}$ & NS \\
\hline \multirow{5}{*}{ Cohesiveness } & 0 & $0.45^{\mathrm{b}}$ & $0.50^{\mathrm{b}}$ & $0.61^{\mathrm{a}}$ & $0.56^{\mathrm{a}}$ & $* *$ \\
\hline & 30 & $0.47^{\mathrm{d}}$ & $0.53^{\mathrm{c}}$ & $0.65^{\mathrm{a}}$ & $0.59^{\mathrm{b}}$ & $* * *$ \\
\hline & 60 & $0.50^{\mathrm{b}}$ & $0.55^{\mathrm{b}}$ & $0.67^{\mathrm{a}}$ & $0.63^{\mathrm{a}}$ & $* *$ \\
\hline & 90 & $0.48^{\mathrm{c}}$ & $0.52^{\mathrm{bc}}$ & $0.64^{\mathrm{a}}$ & $0.58^{\mathrm{ab}}$ & $* *$ \\
\hline & 120 & $0.46^{\mathrm{c}}$ & $0.51^{b c}$ & $0.60^{\mathrm{a}}$ & $0.55^{\mathrm{ab}}$ & $* *$ \\
\hline \multirow{5}{*}{ Gumminess } & 0 & $12.48^{\mathrm{a}}$ & $9.41^{\mathrm{c}}$ & $10.68^{b}$ & $7.72^{d}$ & $* * *$ \\
\hline & 30 & $9.80^{\mathrm{b}}$ & $8.17^{\mathrm{c}}$ & $10.32^{\mathrm{a}}$ & $7.64^{\mathrm{d}}$ & $* * *$ \\
\hline & 60 & $9.66^{\mathrm{a}}$ & $7.70^{c}$ & $8.32^{\mathrm{b}}$ & $6.77^{\mathrm{d}}$ & $* * *$ \\
\hline & 90 & $7.86^{\mathrm{a}}$ & $7.47^{\mathrm{b}}$ & $7.10^{\mathrm{c}}$ & $4.47^{\mathrm{d}}$ & $* * *$ \\
\hline & 120 & $7.72^{\mathrm{a}}$ & $7.40^{\mathrm{b}}$ & $6.64^{\mathrm{c}}$ & $4.40^{\mathrm{d}}$ & $* * *$ \\
\hline \multirow{5}{*}{ Chewiness } & 0 & $8.51^{\mathrm{a}}$ & $6.11^{\mathrm{c}}$ & $6.96^{\mathrm{b}}$ & $5.14^{\mathrm{d}}$ & $* * *$ \\
\hline & 30 & $6.68^{b}$ & $5.55^{\mathrm{c}}$ & $6.80^{\mathrm{a}}$ & $4.83^{d}$ & $* * *$ \\
\hline & 60 & $6.64^{\mathrm{b}}$ & $5.22^{\mathrm{c}}$ & $6.78^{a}$ & $4.52^{\mathrm{d}}$ & $* * *$ \\
\hline & 90 & $5.39^{\mathrm{a}}$ & $4.89^{b}$ & $4.95^{\mathrm{d}}$ & $4.49^{\mathrm{c}}$ & $* * *$ \\
\hline & 120 & $5.25^{\mathrm{a}}$ & $4.75^{\mathrm{c}}$ & $4.90^{\mathrm{b}}$ & $4.45^{\mathrm{d}}$ & $* * *$ \\
\hline \multirow{5}{*}{ Resilience } & 0 & $0.24^{\mathrm{a}}$ & $0.19^{\mathrm{a}}$ & $0.23^{\mathrm{a}}$ & $0.20^{\mathrm{a}}$ & NS \\
\hline & 30 & $0.20^{\mathrm{a}}$ & $0.18^{\mathrm{a}}$ & $0.22^{\mathrm{a}}$ & $0.19^{\mathrm{a}}$ & NS \\
\hline & 60 & $0.19^{\mathrm{a}}$ & $0.18^{\mathrm{a}}$ & $0.21^{\mathrm{a}}$ & $0.18^{\mathrm{a}}$ & NS \\
\hline & 90 & $0.18^{\mathrm{a}}$ & $0.17^{\mathrm{a}}$ & $0.20^{\mathrm{a}}$ & $0.16^{\mathrm{a}}$ & NS \\
\hline & 120 & $0.16^{\mathrm{a}}$ & $0.15^{\mathrm{a}}$ & $0.16^{\mathrm{a}}$ & $0.15^{\mathrm{a}}$ & NS \\
\hline
\end{tabular}

a,b,c,d =Means having different letters in the same raw significantly differed at $\mathrm{p} \geq 0.05$.

LSD $=$ Least significant difference

$*=$ Significant

$* *=$ High significant

$* * *=$ Very high significant

$\mathrm{NS}=$ Not significant 
In a half fat Cheddar cheese, HHP treatment from $100-800 \mathrm{Mpa}$ for $2 \mathrm{hr}$., induced softening of cheeses and increased metability, cohesiveness and chewines (Johnsto et al., 2002).

Generally, Hardiness, Adhesiveness and Springiness significantly difference $(\mathrm{p} \geq 0.05)$ between experimental cheeses at the same storage time. The observation may be due to the proteolysis which softened the cheeses (Polland et al., 2003). These results are in agreement with these reported by (Ozturk et al., 2015).

In general, all cheeses treated with HHP showed an increase of fracture stress as ripening advanced (Table 4), although at day 120, little differences were observed compared with the first day compared to control at the same time.

\section{Sensoryal Evaluation}

Table 5 shows that, the mean flavour and texture scores increased significantly as aging progressed. Generally, at the end of storage period HHP-treated Cheddar cheese gained significantly higher flavour and texture scores than control cheeses. HHP-treated Cheddar cheese at $600 \mathrm{MPa}$ for $20 \mathrm{~min}$. received the highest score for texture and flavour intensity than treated at 200 and $400 \mathrm{MPa}$ for $20 \mathrm{~min}$. and control, and also, were less crumbly and more elastic than control.

All HHP-treated Cheddar cheese showing an increased softness relative to unpressurized control. Similar results were found in goat's milk cheeses treated at $400 \mathrm{MPa}$ (Saldo et al., 2000) that were less crumbly and more elastic than control. Also, these results agree with Reps et al. (1998) who found that pressurized Gouda cheese was more elastic than control.

Table 5. Sensory properties of Cheddar cheese as affected by using different levels of high hydrostatic pressure (HHP)-treatments for 20 min.

\begin{tabular}{|c|c|c|c|c|c|c|c|}
\hline \multirow{2}{*}{$\begin{array}{l}\text { Storage period } \\
\text { (day) }\end{array}$} & \multirow{2}{*}{\multicolumn{2}{|c|}{ Cheese property }} & \multirow[t]{2}{*}{ Control } & \multicolumn{3}{|c|}{ HHP-treatment for $20 \mathrm{~min}}$. & \multirow[t]{2}{*}{ Sign. } \\
\hline & & & & 200 Мра & 400 Мра & $600 \mathrm{Mpa}$ & \\
\hline \multirow{4}{*}{$\mathbf{0}$} & Appearanc & 10 & 8.00 & 8.00 & 8.00 & 8.00 & \\
\hline & Body and texture & 40 & 30.50 & 31.40 & 32.70 & 34.15 & \\
\hline & Flavour & 50 & 38.50 & 38.75 & 39.40 & 40.20 & \\
\hline & Total & 100 & $77.00^{\mathrm{c}}$ & $78.15^{\mathrm{c}}$ & $80.10^{\mathrm{b}}$ & $82.35^{\mathrm{a}}$ & $* * *$ \\
\hline \multirow{4}{*}{30} & Appearanc & 10 & 8.00 & 8.40 & 8.50 & 8.50 & \\
\hline & Body and texture & 40 & 34.80 & 35.60 & 35.70 & 36.40 & \\
\hline & Flavour & 50 & 44.50 & 44.85 & 44.95 & 45.60 & \\
\hline & Total & 100 & $87.30^{\mathrm{c}}$ & $88.85^{\mathrm{b}}$ & $89.15^{\mathrm{b}}$ & $90.50^{\mathrm{a}}$ & $* * *$ \\
\hline \multirow{4}{*}{60} & Appearanc & 10 & 8.50 & 8.75 & 9.00 & 9.00 & \\
\hline & Body and texture & e 40 & 35.00 & 36.35 & 36.65 & 37.35 & \\
\hline & Flavour & 50 & 46.60 & 46.75 & 47.15 & 47.40 & \\
\hline & Total & 100 & $90.10^{\mathrm{d}}$ & $91.85^{\mathrm{c}}$ & $92.80^{\mathrm{b}}$ & $93.75^{\mathrm{a}}$ & $* * *$ \\
\hline \multirow{4}{*}{90} & Appearanc & 10 & 9.00 & 9.00 & 9.00 & 9.00 & \\
\hline & Body and texture & e 40 & 35.00 & 36.75 & 37.00 & 37.60 & \\
\hline & Flavour & 50 & 47.00 & 47.20 & 47.50 & 48.15 & \\
\hline & Total & 100 & $91.00^{\mathrm{c}}$ & $92.95^{b}$ & $93.50^{\mathrm{b}}$ & $94.75^{\mathrm{a}}$ & $* * *$ \\
\hline \multirow{4}{*}{120} & Appearanc & 10 & 9.00 & 9.00 & 9.00 & 9.00 & \\
\hline & Body and texture & e 40 & 35.40 & 36.85 & 37.25 & 37.80 & \\
\hline & Flavour & $\mathbf{5 0}$ & 47.50 & 47.65 & 47.80 & 47.95 & \\
\hline & Total & 100 & $91.90^{\mathrm{c}}$ & $93.50^{\mathrm{b}}$ & $94.00^{b}$ & $94.75^{\mathrm{a}}$ & $* * *$ \\
\hline
\end{tabular}

$\mathrm{a}, \mathrm{b}, \mathrm{c}, \mathrm{d}=$ Means having different letters in the same raw significantly differed at $\mathrm{p} \geq 0.05$.

LSD $=$ Least significant difference

$*=$ Significant $\quad * *=$ High significant $\quad * * *=$ Very high significant $\quad$ NS=Not significant 


\section{Conclusion}

This study was carried out to evaluate the effect HHP on chemical composition, proteolysis, rheological and organoleptic properties of Cheddar cheese during ripening. Cheddar cheese was HHP treated at $200,400,600 \mathrm{Mpa}$ at $25^{\circ} \mathrm{C}$ for $20 \mathrm{~min}$. HHP treatment increased moisture and $\mathrm{pH}$ values of cheese, moreover this treatment increased proteolyss during ripening. HHP-treated Cheddar cheese gained higher organoliptc scores and rheological properties than control cheese. The best treatment and the highest scores was showed in cheese treated with $\mathrm{HHP}$ at $600 \mathrm{MPa}$ at $25^{\circ} \mathrm{C}$ for $20 \mathrm{~min}$.

\section{REFERENCES}

Avila, M., S. Garde, P. Gaya, M. Medina and M. Nunez (2006). Effect of high-pressure treatment and a bacteriocin producing lactic acid culture on the proteolysis, texture and taste of Hispanco cheese. J. Dairy Sci., 89 : 2882-2893.

Awad, A., A.N. Hassan and K. Muthu-Kumara (2005). Application of exopolyshaccaraid producing in reduced-fat cheddar cheese: Texture and melting properties. J. Dairy Sci., 88: 4204-4213.

Bibiana, J., V. Ferragut, B. Guamis and A. Trujillo (2008). The effect of high-pressure treatment at $300 \mathrm{MPa}$ on ripening of ewes' milk cheese. Int. Dairy J., 18: 129-138.

Cheftel, J.C. (1995). High-pressure, microbial inactriation and food preservation. Food Sci. and Technol. Int., 1 : $75-90$.

Crow, V.L., F.G. Martley, T. Coolbear and S.J. Roundhill (1995). The influence of phageassisted lysis of Lactococcus lactis subsp lactis ML8 on Cheddar cheese ripening. Int. Dairy J., 5 : 451-472.

Curtin, A.C. and P.L.H. McSweeny (2004). Catabolism of amino acids in cheese during ripening cheese: chemistry, physics and microbiology, $3^{\text {rd }}$ Ed. General Aspects. London: Elsvier, 435-454.

Daniela, D.V., M.F. Patterson M. Linton and A.L. Kelly (2011). Effect of high-pressure treatment of milk perior to the manufacture on rioening of cammbert cheese. Innovative Food Sci. and Emerg. Tech., 12: 1 - 5.

Daniela, D.V., F. Chevalier, J.A. Donaghy and M.F. Patterson (2012). Effect of high-pressure treatment of milk for cheese manufacture on proteolysis, lipolysis, Texture and functionally of Cheddar during ripening. Innovative Food Sci. and Emerg. Tech., 13: 23-30.

Daniela, D.V., F. Chevalier, J.A. Donaghy, M.F. Patterson, S. Stephan and A.L. Kelly (2010). Manufacture of Cheddar cheese from highpressure treated whale milk. Innovative Food Sci. and Emerg. Tech., 11: 574-579.

Darke, H., A. Barbosa-Canovas and Swanson (1997). High pressure treatment of milk and effects on microbiological and sensory quality of cheddar cheese. J. Food Sci., 62: 842-845.

El-Zeini, H.M., M.A. El-Asser, M.A. El-Asser, S.M.K. Anis and E.A.H. Romeih (2007). Influence of some processing treatments on chemical composition, rheologica properties and microstructure of cast UF. White Soft Cheese. Egypt. J. Dairy Sci., 35 : 57.

Fox, P.F. and J.M. Wallace (1997). Formation of flavour compounds. Adv. Appl. Microbiol., 45: 744-745

Fox, P.F., I.M. Wallace, S. Morga, M. Lynche, E.J. Niland and J. Tobin (1996). Acceleration of cheese ripening. Antonic Van Leuveehoek, $70:$ 271-297.

Gard, S., J.L. Arquse, P. Gaya, M. Medina and M. Nunez (2007). Effect of high pressure treatment on proteolysis and texture of ewe's milk La Serena cheese. Int. Dairy J., 17: $1424-1433$.

Iazmin, S., G. Velazquez, K. Annpon, L. Jose and T. Antonio (2005). Moderatly high hydrostatic pressuring to reduce production of casts of Shrodded cheese: Microstracture, texture and sensory properties of Shredded mild curd Cheddar. J. Food Sci., 70 (4): 286293.

IDF (1991). Rheological and fracture properties of cheese. Int. Dairy Federation, Bulletin, 268. Brussels, Belguim. 
Jin, Z.T. and W.J. Harper (1996). Effect of high pressure treatment on changes of microflora and aroma profile in accelerated ripening of cheese slurry. J. Dairy Sci., 79 (1) : 114.

Johnsto, D.E., M. O'Hagan and D.W. Balmer (2002). Effect of high pressure treatment on the texture and cooking performance of halffat Cheddar cheese. Milch wissenschaft, 57 : $198-201$.

Juan, B., L.J.R. Barron, V. Ferraqut, B. Guamis and A.J. Trujillo $\left(2007_{\mathrm{b}}\right.$ ): Changes in the volatile composition of a semi-hard ewe's milk cheese induced by high-pressure treatment of $300 \mathrm{MPa}$. J. Agric. and Food Chem., 55: 747-754.

Juan, B., V. Ferraqut, M. Buffa, B. Guamis and A.J. Trujillo (2007a). Effect of high pressure on proteolytic enzymes in cheese: Relationship with the proteolytic of ewe's milk cheese. J. Dairy Sci., 90: 2113-3125.

Kosikowski, F.V. (1982). Cheese and Fermented Milk Foods. $3^{\text {rd }}$ Ed. Brooktondale NY : FV Kosikowski and Assoc.

Marshall, R.T. (1992). Standard Methods for the Examination of Dairy Products $16^{\text {th }}$ Ed. American Public Health Association, Washington, DC.

McSweeny, P.L.H. and M.J. Sousa (2000). Biochemical pathways for the production of flavour compounds in cheese during ripening. A Rev., Lait, 80, 293-324

McSweeny, P.L.H. and P.F. Fox (1997). Chemical methods for the characterization of proteolysis in cheese during ripening. Lait, 77: 41-76.

Messens, W., J. Estepar-Garica, K. Dewettnick and A. Hughebaert (1999). Proteolysis of high pressure treated Gouda cheese. Int. Dairy J., 9: 775-782.

Messens, W., K. Dewettnick, J. Vancamp and A. Hughebaert (1998): High pressure brining of Gouda cheese and its effect on the cheese serum. Lebensmittel wissonsschaft und Technol., 31:552-558.

Mondino, A.G., S. Pongiovanni, S. Fumere and L. Rossi (1972): An improved method of plasma deproteination with sulphasalcilic acid for determination amino acid and related compounds. J. Chromatography, 74: 255.

Muir, D.D., E.A. Hunter, J.M. Bank and D.S. Horne (1996). Sensory properties of Cheddar cheese: Changes during maturation. Food Res. Int., 28 : 561-568.

Nienaber, V. and T.H. Shellhammer (2000). Texture study of high pressure processed Cheddar cheese. IFT annual meeting, Dallas, TX, USA, June, PP $10-14$.

O'Reilly, C.F., K.L. Kelly, P.M. Murphy and T. Beresford (2001). High pressure treatment: Applications in cheese manufacture and ripening. Trends in Food Sci. and Technol., 12: 51-59.

O’Reilly, C.F., P.E. O’Connor, K.L. Kelly, T. Beresford and P.M. Murphy $\left(2000_{\mathrm{a}}\right)$. Use of hydrostatic pressure for inactivation of microbial contamination in cheese. Appl. and Environ. Microbiol., 66: 4890-4896.

O'Reilly, C.F., P.M. O'Connor, P.M. Murphy, K.L. Kelly and T.P. Beresford (2002). Effects of high-pressure treatment on viability and autolysis of starter bacteria and proteolysis in Cheddar cheese. Int. Dairy J., 12: 915-922.

Ozturk, M.S.G., J.J. Jaegg, M.E. Johnson and J.A. Lucey (2015). Low-sodium Cheddar sheese effect of fortification of cheese milk with ultrafiltration retentate and highhydrostatic pressure treatmeant of cheese. J. Dairy Sci., 98 : 6731-6726.

Polland, A., F. Shrkat, M.G. Seuret and A.L. Halmos (2003). Texture changes of natural chedder cheese during the maturation process. J. Food Sci., 68 (6): 2611-2616.

Reps, A., P. Kolakowski and F. Dajnowiec (1998). The effect of high pressure on microorganisms and enzymes of ripening cheeses. In NS (Ed). High pressure food science, bioscience and chemistry, Combridge, UK Royal Soc. Chem., 265-270.

Rover, P. (1995). The third dimension of food technology. Technologie Alimentari, 4: 6478.

Rynne, N.M., T.P. Beresford, A.L. Kelly and T.P. Guinee (2004). Effect of milk 
pasteurization temperature and in situ whey protein denaturation on the composition, texture, and heat-induced functionality of heath-fat Cheddar cheese. Int. Dairy J., 14: 989-1001.

Saldo, J., E. Sendra and B. Guamis (2000). High hydrostatic pressure for accelerating ripening of goat's milk cheese: Proteolysis and texture. J. Food Sci., 65: 636-640.

Saldo, J., E. Sendra and B. Guamis (2001). Hard cheese structure after a high hydrostatic pressure treatment at $50 \mathrm{MPa}$ for $72 \mathrm{hr}$.: applied to cheese after brining. Lait., 81: 625-635.

Saldo, J., P.L.H. McSweeny, E. Sendra, A.L. Kelly and B. Guamis (2002). Proteolysis in caprine milk cheese treated by high pressure to accelerate cheese ripening. Int. Dairy J., 12 (1): 35-44.

SAS (2003). Statistical Analysis System. User's Guide. Statistics, (SAS, Cary, North Carolina.).

Thomas, T.D. and G.G. Prichard (1987). Proteolysis enzymes of dairy starter culture. FEMS Microbiol. Rev., 46: 245-268.
Trujillo, A.J., C. Royo, V. Ferragut and B. Guamis (1999). Ripening profiles of Goat's cheese produced from high-pressure treated milk. J. Food Sci., 64 : 833-837.

Trujillo, A.J., M. Capellas, J. Saldo, R. Gerwilla and B. Guamis (2002). Application of highhydrostatic pressure on milk and dairy products: a review. Ennovative Food Sci. and Emerg. Technol., 3 (4): 295-307.

Trujillo, A.J., M. Capellas, M. Buffa, C. Royo, R. Gerwilla, X. Felipe, E. Sendra, J. Saldo, V. Ferragut and B. Guamis (2000). Application of high pressure treatment for cheese production. Food Res. Int., 33: 311316.

Upadhyay, V.K., T. Huppertz, A.L. Kelly and P.L.H. McSweeny (2007). Use of high pressure treatment to attenuate starter bacteria for use as adjuncts for Cheddar cheese manufacture. Innovative Food Sci. and Energ. Technol., 8: 485-492.

Yokoyama, H., N. Sawamura and N. Motobayashi (1992). Method for accelerating cheese ripening. European-Patent-Application EPO 469857 A 1. 


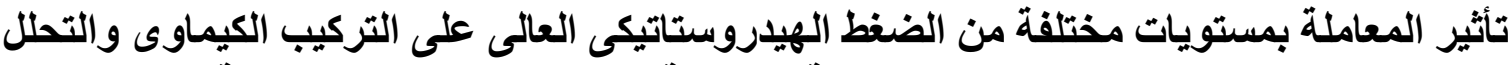

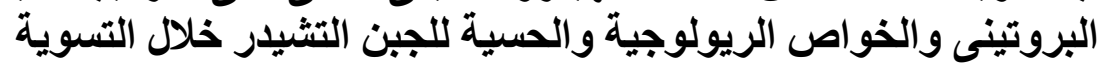

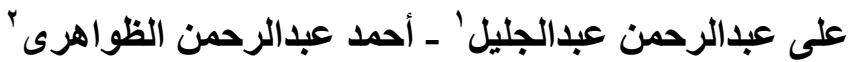

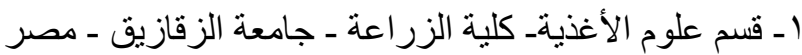

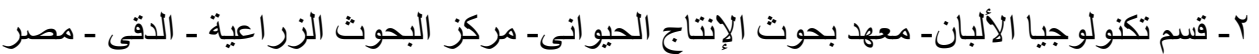

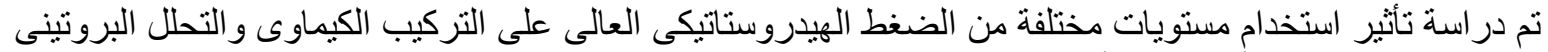

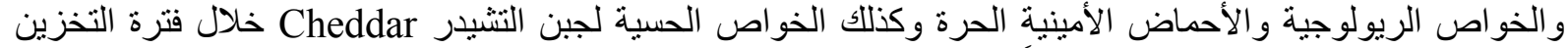

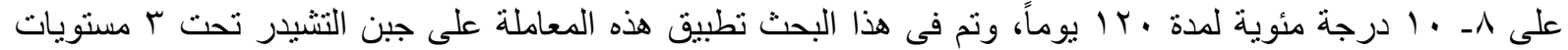

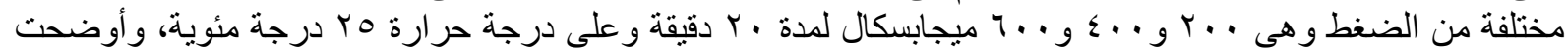

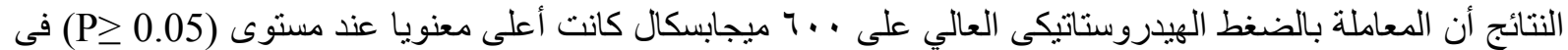

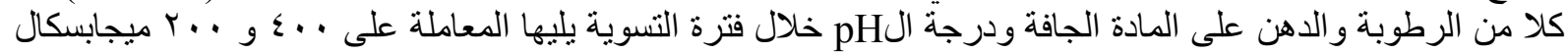

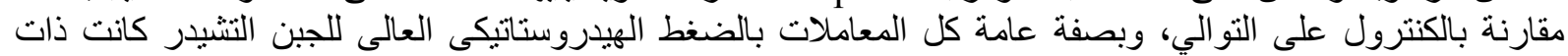

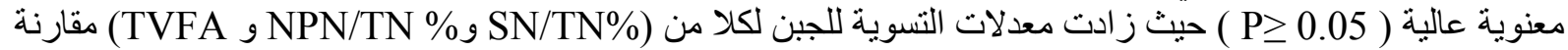

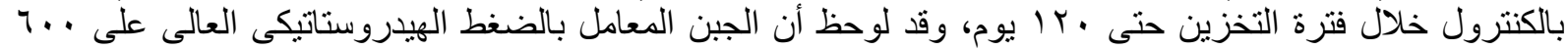

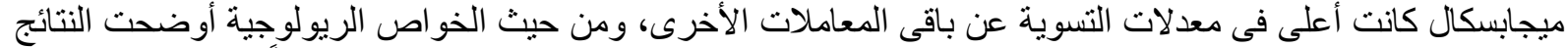

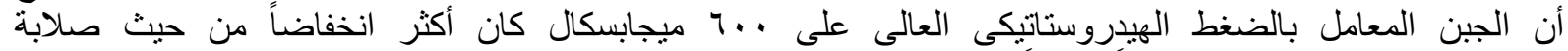

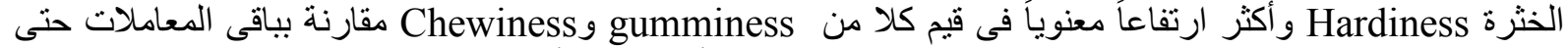

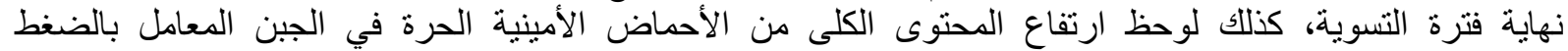

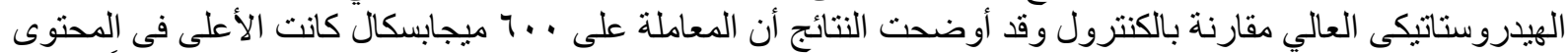

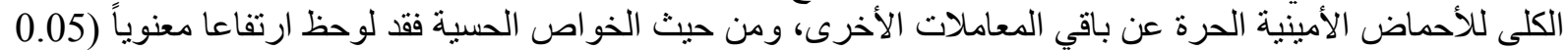

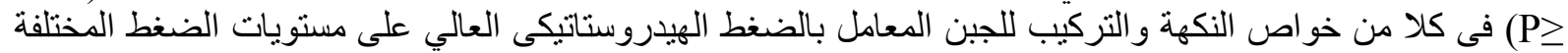

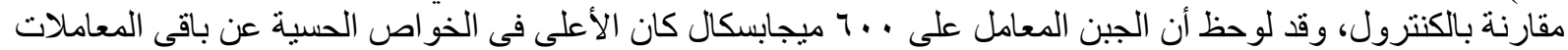

